\title{
Effect of polychlorinated biphenyls on
} osmoregulatory response and apoptosis in GIFT tilapia, Oreochromis niloticus

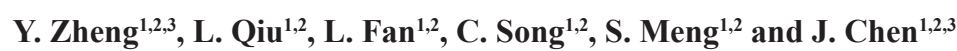

${ }^{1}$ Key Open Laboratory of Ecological Environment and Resources of Inland Fisheries, Freshwater Fisheries Research Center,

Chinese Academy of Fishery Sciences, Wuxi, Jiangsu, China

${ }^{2}$ Key Laboratory of Genetic Breeding and Aquaculture Biology of Freshwater Fishes, Scientific Observing and Experimental Station of Fishery Resources and Environment in the Lower Reaches of the Changjiang River,

Ministry of Agriculture, Wuxi, Jiangsu, China

${ }^{3}$ Wuxi Fisheries College, Nanjing Agricultural University, Wuxi, Jiangsu, China

Corresponding authors: Y. Zheng / J. Chen

E-mail: zhengy@ffrc.cn / chenjz@ffrc.cn

Genet. Mol. Res. 15 (3): gmr.15038620

Received March 21, 2016

Accepted May 17, 2016

Published September 2, 2016

DOI http://dx.doi.org/10.4238/gmr.15038620

Copyright $(2016$ The Authors. This is an open-access article distributed under the terms of the Creative Commons Attribution ShareAlike (CC BY-SA) 4.0 License.

\begin{abstract}
In the present study, GIFT tilapia Oreochromis niloticus were exposed to polychlorinated biphenyls (PCBs) for 7, 14, and 21 days. Over the duration of the exposure, genotoxicity and the activity of $\mathrm{Na}^{+} / \mathrm{K}^{+}$-ATPase (NKA) and $\mathrm{Ca}^{+} / \mathrm{Mg}^{+}$-ATPase (CMA) were measured in the gill, kidney, and intestine, to evaluate changes in osmoregulatory response in $O$. niloticus. Our results showed significant decreases in organic NKA (except in gill tissues after $0.5 \mathrm{mg} / \mathrm{L}$ PCB-exposure) and CMA activity. The results of the genotoxicity assay showed significant increases in atp $1 a 1 a, n k c c 2$ (only in gill tissue), and $f x y d 7$ (except after
\end{abstract}


21 days of $5 \mathrm{mg} / \mathrm{L}$ PCB exposure). We found significant increases in caspase proteins in the liver in the 5-mg/L PCB exposure group, and the transcripts showed dose-dependent increases between treatment groups over the exposure duration. This study presents evidence that chronic exposure to PCB could result in organic osmoregulatory response and hepatic apoptosis in GIFT tilapia.

Key words: Apoptosis; Oreochromis niloticus; Osmoregulatory responses; Polychlorinated biphenyls

\section{INTRODUCTION}

Our previous study indicated that hepatic antioxidant enzymatic activity significantly increased under methomyl exposure in Oreochromis niloticus, which is an ideal subject for toxicity experiments (Meng et al., 2014). The tropical GIFT tilapia (O. niloticus) is suitable for culture in warm waters, and is very sensitive to aquatic environmental factors (Gabriel et al., 2015). Fish genotoxicity, a more sensitive pollution indicator (Chakravarthy et al., 2014), might be a useful biomarker in ecotoxicological studies. The concentration of polychlorinated biphenyls (PCBs) in the aquatic environment ranges from 1.7 to $29.8 \mathrm{ng} / \mathrm{L}$ in the Yangtze River, China (Ge et al., 2014). PCBs function as oxidative stress inducers to produce excess reactive oxygen species, which was shown to result in hepatotoxicity in the Chinese rare minnow (Gobiocypris rarus) (Wu et al., 2014). $\mathrm{Na}^{+} / \mathrm{K}^{+}$-ATPase (NKA) and $\mathrm{Ca}^{+} /$ $\mathrm{Mg}^{+}$-ATPase (CMA) activity are the key endpoints in osmoregulatory pathway, while hepatic caspases are vital in apoptosis pathway. When fish exposed to toxicant, we hypothesized that osmoregulatory response and hepatic apoptosis would be impaired as measured by organic NKA and CMA activity and hepatic caspases, respectively, and that the related transcripts would be enhanced following PCB exposure. The main purpose of the present study was to investigate osmoregulatory responses (organic NKA and CMA activity), apoptosis (hepatic caspases) and transcriptional genotoxicity of freshwater $O$. niloticus in response to 0.5 - and 5-mg/L PCB exposure.

Gill, kidney, and intestine were the main target organs associated with osmoregulatory response in $O$. niloticus exposed to heavy metals, which suggests that NKA and CMA activity can be used as sensitive biomarkers in metal contaminated waters (Atli and Canli, 2011). For example, NKA activity in the kidney was significantly increased in tilapia under cadmium exposure (Garcia-Santos et al., 2015), and it could therefore be used as a sensitive biomarker to assess the health status of tilapia populations (Wu et al., 2015). Tilapia gill NKA and $\mathrm{Ca}^{2+}-$ ATPase could act as sensitive biomarkers in metal-contaminated waters (Eroglu and Canli, 2013). Caspases are a family of protease enzymes playing essential roles in programmed cell death and inflammation. Hepatic caspase 3, 8, and 9 activity in tilapia (O. niloticus) has been shown to increase in both perfluorooctane sulfonate and perfluorooctanoic acid exposed groups (Liu et al., 2007). Apoptosis has been found in Oreochromis mossambicus gill mitochondrion-rich cells in the form of osmoregulatory response under salt water stress (Inokuchi and Kaneko, 2012).

Two NKA a1 isoforms (a-1a and a-1b) are mainly expressed in the gill, and a-1a (NKA a1 polypeptide 1a, atp1a1a) is mainly expressed in freshwater tilapia (Baysoy et al., 2013). Gene transcriptional levels of ion pumps (such as NKA a3-subunit) have been found to show

Genetics and Molecular Research 15 (3): gmr.15038620 
significant increments in tilapia exposed to various stressors (Seale et al., 2014; Moorman et al., 2015). The key transporter associated with the $\mathrm{NaCl}$ transport process is thought to be $\mathrm{Na}^{+} / \mathrm{K}^{+} / 2 \mathrm{Cl}$-cotransporter 1 (NKCC2, $n k c c 2$ ) (Hwang and Lee, 2007). By interacting with NKA, the FXYD domain-containing ion transport regulator $(f x y d)$ has been shown to be involved in teleost osmoregulation (Hu et al., 2014). FXYD7 ( $f x y d 7$ ) is mainly expressed in the brain, and a recent study found that FXYD7 could decrease $\mathrm{K}^{+}$affinity, thus, it contributes to enzyme stimulation at elevated extracellular $\mathrm{K}^{+}$concentrations ( $\mathrm{Li}$ et al., 2013). Currently, the understanding of the function of FXYD7 in tilapia is limited.

\section{MATERIAL AND METHODS}

\section{Experimental design}

The parents for producing GIFT tilapia offspring (O. niloticus) were obtained from the Freshwater Fisheries Research Center of the Chinese Academy of Fishery Sciences, Yixing, where fertilized eggs were maintained. The one-month old $O$. niloticus juveniles that were used in the experiment were acclimatized to the aquarium facility with dechlorinated tap water at $28^{\circ} \pm 1{ }^{\circ} \mathrm{C}$, with $14 \mathrm{~h}: 10 \mathrm{~h} \mathrm{light} /$ dark cycle. The experimental fish were offered feed once a day (feed were purchased from Ningbo Tech-Bank Co. Ltd, Yuyao city, China). Fish (73.65 \pm $3.24 \mathrm{~g}$ ) were selected randomly for the exposure experiments. Throughout the experimental period, water samples were taken before and after each water change, the water conditions were as follows: $\mathrm{pH}, 7.0 \pm 0.5$; dissolved oxygen (tested by YSI 556MPS), $7.25 \pm 0.11 \mathrm{mg} / \mathrm{L}$; total phosphate, $2.05 \pm 0.11 \mathrm{mg} / \mathrm{L}$; total nitrogen and ammonia nitrogen (measured using Nessler's reagent spectrophotometry), $0.54 \pm 0.12$ and $0.46 \pm 0.05 \mathrm{mg} / \mathrm{L}$, respectively; total water hardness (ICP-OES, Optima 7000), $199.1 \pm 10.5 \mathrm{mg} / \mathrm{L} \mathrm{CaCO}_{3}$. The Animal Care and Use Committee of the Nanjing Agricultural University approved the experimental protocol, which was performed in accordance with the Guidelines for the Experimental Animals of the Ministry of Science and Technology (2006, Beijing, China).

The GIFT tilapia $(\mathrm{N}=180)$ were divided into nine groups $(\mathrm{N}=20$ per aquarium, 1500 $\mathrm{L}, 1.5 \mathrm{~m}$ length $\times 1.0 \mathrm{~m}$ width $\times 1.0 \mathrm{~m}$ height). Each group of fish was exposed to $0,0.5$, or 5 $\mathrm{mg} / \mathrm{L} \mathrm{PCB}$, respectively, in triplicate. PCBs were purchased from Sigma-Aldrich (containing PCB28, PCB52, PCB101, PCB118, PCB138, PCB153, and PCB180 at $10 \mathrm{mg} / \mathrm{L}$ per congener). The exposure period followed that used by Eroglu and Canli (2013), and the concentrations were based on previous studies (Wu et al., 2014; Zhao et al., 2015). Fish were exposed to test solutions for 21 days and all exposure solutions were replenished every $48 \mathrm{~h}$ with fresh exposure solutions at the same concentration during the exposure experiment. The control group was also kept for 21 days with fresh water changes but without the addition of PCBs every $48 \mathrm{~h}$. There were no statistically significant differences in fish body weight or length among the different exposure groups. During the experiment, no fish mortality was observed.

\section{Fish sampling}

All fish samples of the exposure and control groups were performed once a week. Samples for both gene expression ( $\mathrm{N}=3$, gill, kidney, intestine, and liver) and biochemical analysis $(\mathrm{N}=3$, gill, kidney, intestine, and liver) were collected per replicate. The samples for the gene expression study were homogenized using Trizol reagent (Invitrogen), frozen

Genetics and Molecular Research 15 (3): gmr.15038620 
in liquid nitrogen, and immediately stored at $-80^{\circ} \mathrm{C}$. Tissues for biochemical analysis were homogenized in ice-cold buffer containing $20 \mathrm{mM}$ Tris- $\mathrm{HCl}, 0.25 \mathrm{M}$ sucrose, and $1 \mathrm{mM}$ EDTA (pH 7.7) with a ratio of $1 / 10$ at $8273 \mathrm{~g}$ for 2-3 min. Homogenates were centrifuged at $13,000 \mathrm{~g}\left(4^{\circ} \mathrm{C}\right)$ for $20 \mathrm{~min}$. The supernatants were collected for determination of total protein levels and ATPase activity.

\section{Determination of osmoregulatory response}

The supernatant above was analyzed in triplicate for the NKA and CMA activity assays, using commercial kits purchased from Nanjing Jiancheng Bioengineering Institute (Nanjing, China). Tests were quantified spectrophotometrically with a PowerWave XS2 (BioTek Instruments Inc., Winooski, VT, USA).

The final assay concentrations to measure tissue NKA and CMA activities (gill, kidney, and intestine) were $40 \mathrm{mM}$ Tris- $\mathrm{HCl}, 120 \mathrm{mM} \mathrm{NaCl}, 20 \mathrm{mM} \mathrm{KCl}, 3 \mathrm{mM} \mathrm{MgCl}, 7.7 \mathrm{pH}$, and $1 \mathrm{mM}$ ouabain. In addition, an incubation medium ( $\mathrm{pH}$ 7.7) containing $40 \mathrm{mM}$ Tris-HCl, 4 $\mathrm{mM} \mathrm{MgCl}, 1 \mathrm{mM} \mathrm{CaCl}$, and $1 \mathrm{mM} \mathrm{EGTA}$ was used for measuring the CMA activity. For measuring ATPase activity, $50 \mu \mathrm{L}$ enzyme suspension ( $100 \mu$ g protein) was added to $850 \mu \mathrm{L}$ incubation medium and was preincubated for $5 \mathrm{~min}$ at $37^{\circ} \mathrm{C}$. The reaction was started by the addition of $100 \mu \mathrm{L} \mathrm{Na}{ }_{2} \mathrm{ATP}(3 \mathrm{mM})$ and 30 min incubation. The reaction was stopped by adding $500 \mu \mathrm{L}$ of ice-cold distilled water. Appropriate blanks were included with each assay to correct for non-enzymatic hydrolysis of ATP. $\mathrm{KH}_{2} \mathrm{PO} 4(25-250 \mu \mathrm{M})$ was used as Pi standard and the spectrophotometric analysis was carried out at $390 \mathrm{~nm}$ using a Cecil 5000 series spectrometer. Specific NKA activity was calculated from the inorganic phosphate liberated from ATP using the differences between the presence (CMA activity) and absence (Total-ATPase activity) of the ouabain. CMA activity was measured as the absorbance difference between the presence and absence of $\mathrm{CaCl}_{2}$. All assays were carried out in triplicate and ATPase activities were calculated as $\mu \mathrm{mol} \mathrm{Pi} / \mathrm{mg}$ prot $/ \mathrm{h}$. Total protein levels were determined according to Lowry et al. (1951) and bovine serum albumin was used as standard.

\section{Determination of caspases}

Hepatic caspase 3, 8, and 9 activity was measured by using caspase 3, 8, and 9 Activity Assay Kits (Nanjing Kaiji Biotechnology, China), respectively, following the method of Genestier et al. (1998). Briefly, liver samples were homogenized in lysate buffer and the homogenate were centrifuged at $15,000 \mathrm{~g}$ for $20 \mathrm{~min}$ at $4^{\circ} \mathrm{C}$. Then, the supernatants were collected and caspase 3 , 8 , and 9 activity were measured by using substrate peptides Ac-DEVD-pNA.

\section{RNA extraction, reverse transcription (RT), and $q R T$ polymerase chain reaction (PCR)}

Total RNAs were extracted from the gill, kidney, intestine, and liver of control and PCB exposed GIFT tilapia juveniles, using Trizol reagent and were subsequently treated with RNase-free DNase I (Fermentas, Canada). To investigate genomic DNA contamination and to verify the total RNA quality, the total RNA was loaded on a $1 \%$ agarose gel stained with $\mathrm{EtBr}$ (Sigma-Aldrich). We then investigated the 18/28S ribosomal RNA integrity using the spectrophotometric method (NanoDrop 1000, Thermo Scientific, USA). After determining RNA quality, cDNAs were synthesized from $3 \mu \mathrm{g}$ DNase I-treated total RNA, using the

Genetics and Molecular Research 15 (3): gmr.15038620 
M-MLV First Strand cDNA Kit (Invitrogen) with oligo (dT) 12-18 primers in a $20-\mu \mathrm{L}$ final volume, according to the manufacturer instructions. The cDNAs were used for cloning genes and carrying out gene expression analysis after normalization.

The qRT-PCR was performed using the CFX96 Real-Time PCR System (Bio-Rad, USA) with SYBR (TaKaRa, Japan). After normalization of each cDNA sample, the qRT-PCRs were carried out using $1 \mathrm{X}$ SYBR Premix Ex Taq ${ }^{\mathrm{TM}}, 0.4 \mu \mathrm{M}$ each primer, and $2.5 \mu \mathrm{L}$ RT reaction solution in a final volume of $25 \mu \mathrm{L}$ in triplicate. The reaction was initially denatured at $95^{\circ} \mathrm{C}$ for $30 \mathrm{~s}$, followed by 40 cycles of denaturation at $95^{\circ} \mathrm{C}$ for $5 \mathrm{~s}$ and annealing at $60^{\circ} \mathrm{C}$ for $30 \mathrm{~s}$. A melt curve analysis was performed at the end of each PCR thermal profile to assess the amplification specificity.

$\beta$-actin was the most stable reference gene under PCB exposure in our study, based on the selection method described by Zheng et al. (2014). The qRT-PCR primers for $\beta$-actin, atp $1 a 1 a, n k c c 2$, fxyd7, caspase 3, caspase 8, and caspase 9 are shown in Table S1. Caspase genes were identified in the liver, whereas atp $1 a 1 a, n k c c 2$, and $f x y d 7$ were observed in the gill, kidney, and intestine. Changes in expression levels of these genes after PCB exposure were calculated using the $2^{-\Delta \Delta C t}$ method with the formula, $\mathrm{F}=2^{-\Delta \Delta \mathrm{Ct}}, \Delta \Delta \mathrm{Ct}=\left(\mathrm{C}_{\mathrm{t} \text {, target gene }}-\mathrm{C}_{\mathrm{t}, \text { B-actin }}\right)$ PCBs $-\left(\mathrm{C}_{\mathrm{t} \text {, target gene }}-\mathrm{C}_{\mathrm{t}, \boldsymbol{\beta} \text {-actin }}\right)_{\text {control }}$ (Livak and Schmittgen, 2001).

\section{Statistical analysis}

All the experimental data are reported as means \pm SD. Data were tested for normality (Shapiro-Wilk test) and homogeneity of variance (Levene's test) prior to analysis. The data were analyzed with one-way analysis of variance (ANOVA) followed by the least significant difference test (Ahmad et al., 2006) using SPSS Statistics 18.0 (SPSS Inc., Chicago, IL, USA), with $\mathrm{P}<0.05$ indicating a significant difference. Data that did not conform to the assumptions of normality and homoscedasticity were transformed $(\log 10)$ and then analyzed as described above.

\section{RESULTS}

\section{NKA and CMA activity}

The tissue NKA and CMA activities (gill, kidney, and intestine) are shown in Table 1. Gill NKA activity in the $5 \mathrm{mg} / \mathrm{L}$ PCB exposure group were significantly decreased (after 7, 14, and 21 days) compared to both the control and $0.5 \mathrm{mg} / \mathrm{L} \mathrm{PCB}$ exposure groups. Compared to the control group, both kidney and intestine NKA activity showed a significant decline both in the 0.5 and $5 \mathrm{mg} / \mathrm{L}$ PCB exposure groups at all three sample times. The kidney and intestinal NKA activity in the 5-mg/L PCB exposure group were also significantly lower than in the 0.5 $\mathrm{mg} / \mathrm{L}$ PCB exposure group (Table 1).

The same patterns as found for NKA were found for kidney and intestinal CMA activity, which were significantly reduced in both the $0.5-$ and 5-mg/L PCB exposure groups in a dose-dependent manner. Compared to the control group, the gill CMA activity was significantly repressed in all PCB exposure groups, whereas no significant differences were found between the two PCB exposed groups.

Genetics and Molecular Research 15 (3): gmr.15038620 
Table 1. Tissue NKA and CMA activity of Oreochromis niloticus under PCB exposure.

\begin{tabular}{c|l|c|c|c|c|c|c}
\hline \multirow{2}{*}{ Day } & Treatment (mg/L) & \multicolumn{2}{|c|}{ Gill activity (U/g prot) } & Kidney activity (U/g prot) & \multicolumn{2}{c}{ Intestine activity (U/g prot) } \\
\cline { 3 - 8 } & & NKA & CMA & NKA & CMA & NKA & CMA \\
\hline \multirow{7}{*}{7} & Control & $25.66 \pm 6.32^{\mathrm{a}}$ & $7.95 \pm 1.24^{\mathrm{a}}$ & $26.25 \pm 4.92^{\mathrm{a}}$ & $5.12 \pm 1.10^{\mathrm{a}}$ & $20.14 \pm 3.22^{\mathrm{a}}$ & $6.62 \pm 1.10^{\mathrm{a}}$ \\
\cline { 2 - 8 } & 0.5 & $24.14 \pm 3.26^{\mathrm{a}}$ & $5.24 \pm 1.02^{\mathrm{b}} \downarrow$ & $22.65 \pm 2.32^{\mathrm{b}} \downarrow$ & $4.26 \pm 0.45^{\mathrm{b}} \downarrow$ & $18.62 \pm 2.13^{\mathrm{b}} \downarrow$ & $4.12 \pm 0.87^{\mathrm{b}} \downarrow$ \\
\cline { 2 - 8 } & 5 & $19.23 \pm 3.49^{\mathrm{b}} \downarrow$ & $4.67 \pm 1.19^{\mathrm{b}} \downarrow$ & $18.15 \pm 3.09^{\mathrm{c}} \downarrow$ & $3.01 \pm 0.86^{\mathrm{c}} \downarrow$ & $17.52 \pm 1.94^{\mathrm{c}} \downarrow$ & $3.12 \pm 0.67^{\mathrm{c}} \downarrow$ \\
\hline \multirow{2}{*}{14} & Control & $25.45 \pm 4.25^{\mathrm{a}}$ & $7.02 \pm 1.47^{\mathrm{a}}$ & $24.18 \pm 3.91^{\mathrm{a}}$ & $6.24 \pm 0.58^{\mathrm{a}}$ & $20.47 \pm 3.64^{\mathrm{a}}$ & $6.49 \pm 0.96^{\mathrm{a}}$ \\
\cline { 2 - 8 } & 0.5 & $27.44 \pm 3.64^{\mathrm{a}}$ & $5.16 \pm 0.95^{\mathrm{b}} \downarrow$ & $21.43 \pm 2.52^{\mathrm{b}} \downarrow$ & $4.15 \pm 0.46^{\mathrm{b}} \downarrow$ & $18.23 \pm 0.96^{\mathrm{b}} \downarrow$ & $5.03 \pm 0.94^{\mathrm{b}} \downarrow$ \\
\cline { 2 - 8 } & 5 & $18.79 \pm 5.41^{\mathrm{b}} \downarrow$ & $4.47 \pm 0.89^{\mathrm{b}} \downarrow$ & $17.69 \pm 1.98^{\mathrm{c}} \downarrow$ & $3.25 \pm 0.51^{\mathrm{c}} \downarrow$ & $16.47 \pm 0.64^{\mathrm{c}} \downarrow$ & $3.96 \pm 1.00^{\mathrm{c}} \downarrow$ \\
\hline \multirow{2}{*}{21} & Control & $25.88 \pm 3.21^{\mathrm{a}}$ & $7.61 \pm 2.31^{\mathrm{a}}$ & $26.96 \pm 2.43^{\mathrm{a}}$ & $6.24 \pm 1.51^{\mathrm{a}}$ & $20.68 \pm 2.65^{\mathrm{a}}$ & $6.75 \pm 2.11^{\mathrm{a}}$ \\
\cline { 2 - 8 } & 0.5 & $26.93 \pm 3.01^{\mathrm{a}}$ & $4.95 \pm 0.92^{\mathrm{b}} \downarrow$ & $23.01 \pm 1.86^{\mathrm{b}} \downarrow$ & $4.50 \pm 0.61^{\mathrm{b}} \downarrow$ & $17.29 \pm 1.06^{\mathrm{b}} \downarrow$ & $5.14 \pm 0.64^{\mathrm{b}} \downarrow$ \\
\cline { 2 - 8 } & 5 & $20.38 \pm 3.66^{\mathrm{b}} \downarrow$ & $5.48 \pm 0.96^{\mathrm{b}} \downarrow$ & $19.64 \pm 0.98^{\mathrm{c}} \downarrow$ & $3.20 \pm 0.31^{\mathrm{c}} \downarrow$ & $15.78 \pm 1.04^{\mathrm{c}} \downarrow$ & $3.58 \pm 0.51^{\mathrm{c}} \downarrow$ \\
\hline
\end{tabular}

$\uparrow$ : up-regulation, $\downarrow$ : down-regulation. Different lower-case letters indicate statistically significant differences $(\mathrm{P}<0.05)$.

\section{Caspase activity}

The activity of hepatic caspase 3 is shown in Figure 1 . Caspase 3 activity was significantly increased compared to the control group in both the 0.5 - (increased by $169 \%$ relative to the control group) and 5-mg/L (increased by 288\%) PCB exposed groups at 14 days. In contrast, after 21 days, a significant increase was found only in the 5-mg/L PCB exposed group (which increased by $273 \%$ ). In caspase 8 , only the $5-\mathrm{mg} / \mathrm{L}$ PCB exposure groups showed a significant increase at all time points (at 7, 14, and 21 days the increase was 188, 346, and 264\%, respectively) (Figure 2). Likewise, caspase 9 activity showed a significant increase in the $5-\mathrm{mg} / \mathrm{L} \mathrm{PCB}$ exposure group, but only at 14 and 21 days (increased by 176 and $266 \%$, respectively; Figure 3 ).

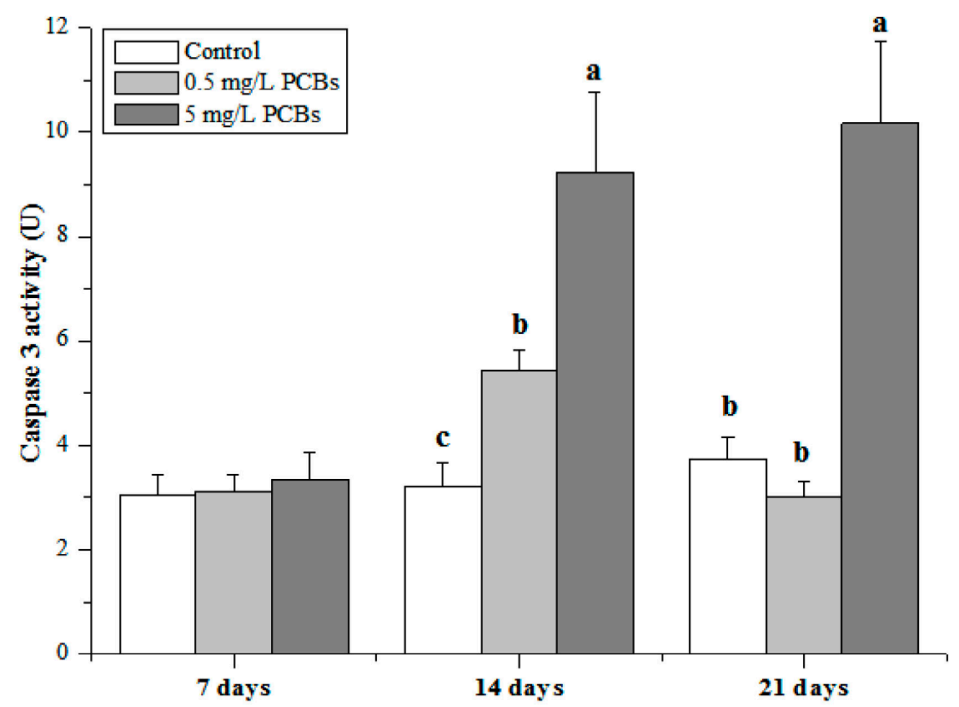

Figure 1. Caspase 3 activity of Oreochromis niloticus under PCB exposure. Different lower-case letters indicate statistically significant differences $(\mathrm{P}<0.05)$.

Genetics and Molecular Research 15 (3): gmr.15038620 


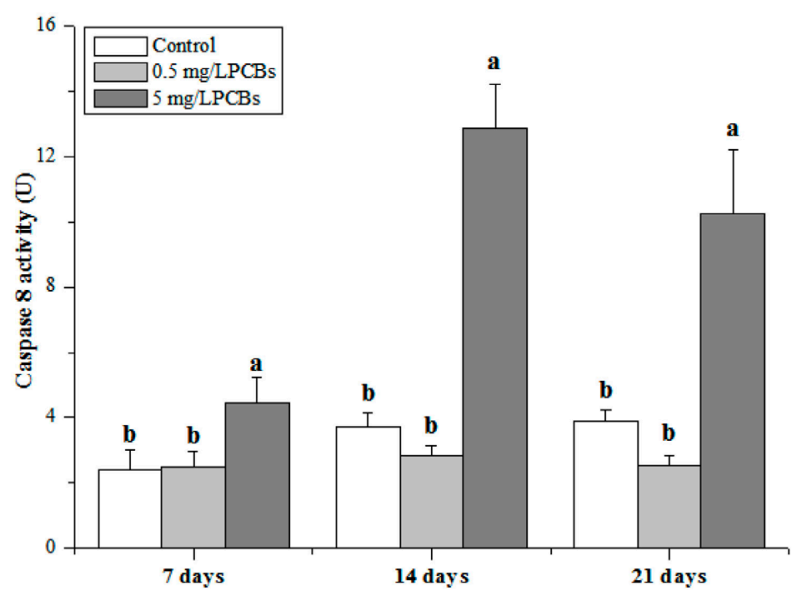

Figure 2. Caspase 8 activity of Oreochromis niloticus under PCB exposure. Different lower-case letters indicate statistically significant differences $(\mathrm{P}<0.05)$.

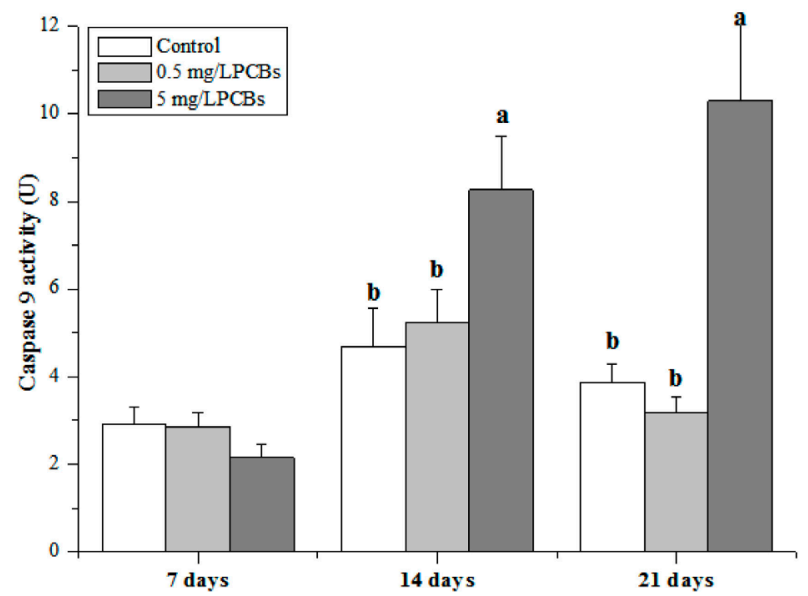

Figure 3. Caspase 9 activity of Oreochromis niloticus under PCB exposure. Different lower-case letters indicate statistically significant differences $(\mathrm{P}<0.05)$.

\section{Genotoxicology}

The gene expression profiles of the osmoregulatory response-signaling pathway (atp $1 a 1 a, n k c c 2$, and $f x y d 7$ ) are shown in Table 2. The atp $1 a 1 a$ transcripts of the three tissues showed significant increases in a dose-dependent manner at all sample time points. The fxyd7 transcripts revealed significant dose-dependent increases after 7 and 14 days' PCB exposure. In contrast, after 21 days of exposure, a significant increase was observed in the $0.5-\mathrm{mg} / \mathrm{L}$ PCB exposure group, whereas a decrease was found in the $5-\mathrm{mg} / \mathrm{L}$ treatment group. Gill nkcc2 transcripts demonstrated dose-dependent increases in both the 0.5 and $5 \mathrm{mg} / \mathrm{L} \mathrm{PCB}$ exposure groups at all sample times, whereas no differences were found in kidney or intestine $n k c c 2$ transcripts. 


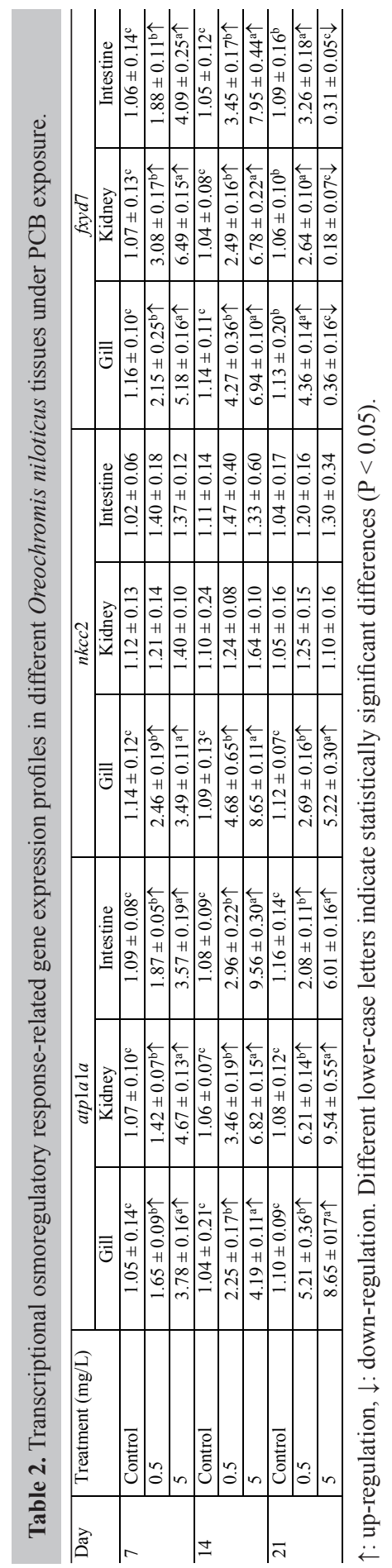

Genetics and Molecular Research 15 (3): gmr.15038620 
The hepatic gene expression profiles of the apoptosis signaling pathway (caspase 3, 8, and 9) are shown in Table 3. Hepatic caspase 3, 8, and 9 transcripts were all significantly higher in the 5-mg/L PCB exposure group than in the $0.5-\mathrm{mg} / \mathrm{L}$ PCB exposure groups at all time points, and both the $0.5-$ and $5-\mathrm{mg} / \mathrm{L} \mathrm{PCB}$ exposure groups were significantly higher than the control group, which suggest dose-dependent increments between treatment groups.

\begin{tabular}{|c|c|c|c|c|}
\hline Day & Treatment $(\mathrm{mg} / \mathrm{L})$ & caspase 3 & caspase 8 & caspase 9 \\
\hline \multirow[t]{3}{*}{7} & Control & $1.06 \pm 0.08^{\mathrm{c}}$ & $1.12 \pm 0.09^{\mathrm{c}}$ & $1.10 \pm 0.17^{\mathrm{c}}$ \\
\hline & 0.5 & $2.16 \pm 0.14^{\mathrm{b} \uparrow}$ & $3.11 \pm 0.17^{\mathrm{b} \uparrow}$ & $2.67 \pm 0.16^{\mathrm{b} \uparrow}$ \\
\hline & 5 & $6.26 \pm 0.18^{\mathrm{a} \uparrow}$ & $5.32 \pm 0.24^{\mathrm{a} \uparrow}$ & $7.79 \pm 0.57^{\mathrm{a} \uparrow}$ \\
\hline \multirow[t]{3}{*}{14} & Control & $1.02 \pm 0.07^{\mathrm{c}}$ & $1.09 \pm 0.07^{\mathrm{c}}$ & $1.14 \pm 0.10^{\mathrm{c}}$ \\
\hline & 0.5 & $3.49 \pm 0.19^{\mathrm{b} \uparrow}$ & $2.66 \pm 0.10^{\mathrm{b} \uparrow}$ & $4.78 \pm 0.24^{\mathrm{b} \uparrow}$ \\
\hline & 5 & $6.81 \pm 0.44^{\mathrm{a} \uparrow}$ & $5.19 \pm 0.46^{\mathrm{a} \uparrow}$ & $6.66 \pm 0.77^{\mathrm{a} \uparrow}$ \\
\hline \multirow[t]{3}{*}{21} & Control & $1.16 \pm 0.11^{\mathrm{c}}$ & $1.06 \pm 0.10^{\mathrm{c}}$ & $1.11 \pm 0.11^{\mathrm{c}}$ \\
\hline & 0.5 & $3.67 \pm 0.65^{\mathrm{b} \uparrow}$ & $3.51 \pm 0.29^{\mathrm{b} \uparrow}$ & $3.09 \pm 0.48^{\mathrm{b} \uparrow}$ \\
\hline & 5 & $7.31 \pm 0.44^{\mathrm{a} \uparrow}$ & $6.00 \pm 0.80^{\mathrm{a} \uparrow}$ & $5.34 \pm 0.30^{\mathrm{a} \uparrow}$ \\
\hline
\end{tabular}

$\uparrow$ : up-regulation, $\downarrow$ : down-regulation. Different lower-case letters indicate statistically significant differences $(\mathrm{P}<0.05)$.

\section{DISCUSSION}

The present study focused on investigating the organic osmoregulatory response and hepatic apoptosis in tilapia during PCB exposure. Our results showed that NKA and CMA activity (in the gill, kidney, and intestine) were significantly reduced, with the exception of the $0.5-\mathrm{mg} / \mathrm{L}$ PCB exposure group in gill tissue. These results agree with results observed in tilapia following $\mathrm{Cu}$-exposure (Wu et al., 2015) as well as following $\mathrm{Zn}, \mathrm{Cd}$, and combined Zn-Cd exposure (Eroglu and Canli, 2013). Lerner et al. (2007) reported that juvenile Atlantic salmon (Salmo salar) exposed to PCB-1 or PCB-10 during smolting exhibited a dose-dependent reduction in preference for seawater. The current study implies that dose-dependent changes also in organic NKA activity (as for the related genes, except for kidney and intestinal $n k c c 2$ transcripts), CMA activity, and hepatic caspase transcripts. We speculate that NKA/CMA activity and hepatic caspase transcripts could act as sensitive biomarkers for different concentrations of PCB exposure in tilapia. Further studies are needed to explore the actual mechanism of how PCBs work in different pathways (based on different responses at various exposure time points).

When the fish gill energy faces acute transfer, phosphocreatine acts as an energy source to meet the osmoregulatory demand through the activity of NKA activity. In the present study, atp $1 a 1 a$ (NKA), $n k c c 2$ (NKA transporter) and $f x y d 7$ (NKA transport regulator) were detected in three osmoregulatory response-related tissues. When faced with a hyperosmotic challenge, the transcripts of organic osmoregulatory response-related genes (gill $n k c c 2$, atp $1 a 1 a$, and $f x y d 7$ ) were found to be induced. This is consistent with the results found in a previous study in which tilapia were transferred from freshwater to seawater (Moorman et al., 2015). Kidney and intestinal $n k c c 2$ transcripts were unchanged in the present study. The cause for this may be that either $n k c c 2$ transcripts were generally lower in the middle segments of the intestine, or are generally more highly expressed in seawater-acclimated fish, compared with freshwater-acclimated fish (Seale et al., 2014). Our results suggested that PCB exposure not only accelerates the acute transfer of ions in the gill, but also ion uptake/ excretion in osmoregulatory response-related organs. Hu et al. (2014) reported that gill and kidney $f x y d 11 / 12$ transcripts were negatively correlated with NKA activity in spotted scat

Genetics and Molecular Research 15 (3): gmr.15038620 
(Scatophagus argus), whereas intestinal fxyd11/12 correlated positively with NKA activity. In the present study, $f x y d 7$ transcripts were significantly up-regulated, suggesting that $f x y d 7$ is involved in the osmoregulatory response in tilapia following PCB exposure (Hu et al., 2014).

Free ceramide production, resulting from osmoregulatory response, serves as an important stress-signaling molecule in apoptosis (Mizushima et al., 1996). In caged $O$. niloticus, Franco et al. (2010) found caspase 3 activation in polluted sites of industrial cities in southern Brazil. Kumar et al. (2009) demonstrated that up-regulation of serum caspase 3 of $O$. mossambicus might contribute to the decreased phagocytic activity upon exposure to hyperosmotic solutions. It has also been reported that prolonged apoptosis occurred in O. mossambicus exposed to elevated salinity in vitro (Kammerer and Kültz, 2009), which suggests that caspase proteins are usually induced when fish are faced with long-term exposure to osmoregulatory stress. Yadetie et al. (2014) demonstrated that genes associated with apoptosis pathways were significantly enriched in juvenile Atlantic cod (Gadus morhua) exposed to PCB153 (at $0.5,2$, and $8 \mathrm{mg} / \mathrm{kg}$ body weight) for two weeks. The current study revealed a significant activation of caspase 3 (except for at 7 days), 8, and 9 (except for at 7 days) in the 5-mg/L PCB exposure groups, and that hepatic caspase (3, 8, and 9) transcripts were also significantly enhanced. This suggests that hepatic apoptosis was impaired in GIFT tilapia under PCB exposure.

\section{ACKNOWLEDGMENTS}

We thank Kamira Barry for providing grammar and spelling check of the manuscript. Research supported by the Special Fund of Fundamental Scientific Research Business Expense for Central Public Research Institutes (\#2015JBFR03) and the China Agriculture Research System (\#CARS-49).

\section{REFERENCES}

Ahmad I, Maria VL, Oliveira M, Pacheco M, et al. (2006). Oxidative stress and genotoxic effects in gill and kidney of Anguilla Anguilla L. exposed to chromium with or without pre-exposure to b-naphthoflavone. Mut. Res. 608: 16-28. http://dx.doi.org/10.1016/j.mrgentox.2006.04.020

Atli $\mathrm{G}$ and Canli M (2011). Essential metal $(\mathrm{Cu}, \mathrm{Zn})$ exposures alter the activity of ATPases in gill, kidney and muscle of tilapia Oreochromis niloticus. Ecotoxicology 20: 1861-1869.http://dx.doi.org/10.1007/s10646-011-0724-z

Baysoy E, Atli G and Canli M (2013). The effects of salinity and salinity+metal (chromium and lead) exposure on ATPase activity in the gill and intestine of tilapia Oreochromis niloticus. Arch. Environ. Contam. Toxicol. 64: 291-300. http:// dx.doi.org/10.1007/s00244-012-9825-9

Chakravarthy S, Sadagopan S, Nair A and Sukumaran SK (2014). Zebrafish as an in vivo high-throughput model for genotoxicity. Zebrafish 11: 154-166.http://dx.doi.org/10.1089/zeb.2013.0924

Eroglu A and Canli M (2013). Effects of Cd, Zn and Cd $+\mathrm{Zn}$ combination on ATPase activity in the gill and muscle of tilapia (Oreochromis niloticus). Bull. Environ. Contam. Toxicol. 91: 420-425.http://dx.doi.org/10.1007/s00128-013-1076-6

Franco JL, Trevisan R, Posser T, Trivella DB, et al. (2010). Biochemical alterations in caged Nile tilapia Oreochromis niloticus. Ecotoxicol. Environ. Saf. 73: 864-872.http://dx.doi.org/10.1016/j.ecoenv.2010.03.002

Gabriel NN, Qiang J, Ma XY, He J, et al. (2015). Dietary Aloe vera improves plasma lipid profile, antioxidant, and hepatoprotective enzyme activities in GIFT-tilapia (Oreochromis niloticus) after Streptococcus iniae challenge. Fish Physiol. Biochem. 41: 1321-1332.http://dx.doi.org/10.1007/s10695-015-0088-z

Garcia-Santos S, Monteiro S, Malakpour-Kolbadinezhad S, Fontaínhas-Fernandes A, et al. (2015). Effects of Cd injection on osmoregulation and stress indicators in freshwater Nile tilapia. Comp. Biochem. Physiol. C Toxicol. Pharmacol. 167: 81-89.

Ge J, Yun X, Liu M, Yang Y, et al. (2014). Distribution, potential source and ecotoxicological risk of polychlorinated biphenyls and polybrominated diphenyl ethers in the surface water of the Three Gorges Dam region of the Yangtze River, China. Ecotoxicology 23: 978-987.http://dx.doi.org/10.1007/s10646-014-1241-7

Genetics and Molecular Research 15 (3): gmr.15038620 
Genestier L, Prigent AF, Paillot R, Quemeneur L, et al. (1998). Caspase-dependent ceramide production in Fas- and HLA class I-mediated peripheral T cell apoptosis. J. Biol. Chem. 273: 5060-5066. http://dx.doi.org/10.1074/jbc.273.9.5060

$\mathrm{Hu}$ P, Li S, Zhong Y, Mu X, et al. (2014). Identification of fxyd genes from the spotted scat (Scatophagus argus): molecular cloning, tissue-specific expression, and response to acute hyposaline stress. Comp. Biochem. Physiol. B Biochem. Mol. Biol. 174: 15-22. http://dx.doi.org/10.1016/j.cbpb.2014.05.002

Hwang PP and Lee TH (2007). New insights into fish ion regulation and mitochondrion-rich cells. Comp. Biochem. Physiol. A Mol. Integr. Physiol. 148: 479-497.http://dx.doi.org/10.1016/j.cbpa.2007.06.416

Inokuchi M and Kaneko T (2012). Recruitment and degeneration of mitochondrion-rich cells in the gills of Mozambique tilapia Oreochromis mossambicus during adaptation to a hyperosmotic environment. Comp. Biochem. Physiol. A Mol. Integr. Physiol. 162: 245-251.http://dx.doi.org/10.1016/j.cbpa.2012.03.018

Kammerer BD and Kültz D (2009). Prolonged apoptosis in mitochondria-rich cells of tilapia (Oreochromis mossambicus) exposed to elevated salinity. J. Comp. Physiol. B 179: 535-542. http://dx.doi.org/10.1007/s00360-008-0333-1

Kumar VB, Jiang IF, Yang HH and Weng CF (2009). Effects of serum on phagocytic activity and proteomic analysis of tilapia (Oreochromis mossambicus) serum after acute osmotic stress. Fish Shellfish Immunol. 26: 760-767. http:// dx.doi.org/10.1016/j.fsi.2009.03.005

Lerner DT, Björnsson BT and McCormick SD (2007). Effects of aqueous exposure to polychlorinated biphenyls (Aroclor 1254) on physiology and behavior of smolt development of Atlantic salmon. Aquat. Toxicol. 81: 329-336. http:// dx.doi.org/10.1016/j.aquatox.2006.12.018

Li B, Hertz L and Peng L (2013). Cell-specific mRNA alterations in $\mathrm{Na}^{+}, \mathrm{K}^{+}$-ATPase $\mathrm{a}$ and $\mathrm{b}$ isoforms and FXYD in mice treated chronically with carbamazepine, an anti-bipolar drug. Neurochem. Res. 38: 834-841. http://dx.doi. org/10.1007/s11064-013-0986-3

Liu C, Yu K, Shi X, Wang J, et al. (2007). Induction of oxidative stress and apoptosis by PFOS and PFOA in primary cultured hepatocytes of freshwater tilapia (Oreochromis niloticus). Aquat. Toxicol. 82: 135-143. http://dx.doi. org/10.1016/j.aquatox.2007.02.006

Livak KJ and Schmittgen TD (2001). Analysis of relative gene expression data using real-time quantitative PCR and the $2^{\text {-DDCT }}$ method. Methods 25: 402-408. http://dx.doi.org/10.1006/meth.2001.1262

Lowry OH, Rosebrough NJ, Farr AL and Randall RJ (1951). Protein measurement with the Folin phenol reagent. J. Biol. Chem. 193: 265-275.

Meng SL, Chen JZ, Hu GD, Song C, et al. (2014). Effects of chronic exposure of methomyl on the antioxidant system in liver of Nile tilapia (Oreochromis niloticus). Ecotoxicol. Environ. Saf. 101: 1-6. http://dx.doi.org/10.1016/j. ecoenv.2013.10.020

Mizushima N, Koike R, Kohsaka H, Kushi Y, et al. (1996). Ceramide induces apoptosis via CPP32 activation. FEBS Lett. 395: 267-271. http://dx.doi.org/10.1016/0014-5793(96)01050-2

Moorman BP, Lerner DT, Grau EG and Seale AP (2015). The effects of acute salinity challenges on osmoregulation in Mozambique tilapia reared in a tidally changing salinity. J. Exp. Biol. 218: 731-739. http://dx.doi.org/10.1242/ jeb.112664

Seale AP, Stagg JJ, Yamaguchi Y, Breves JP, et al. (2014). Effects of salinity and prolactin on gene transcript levels of ion transporters, ion pumps and prolactin receptors in Mozambique tilapia intestine. Gen. Comp. Endocrinol. 206: 146154. http://dx.doi.org/10.1016/j.ygcen.2014.07.020

Wu F, Zheng Y, Gao J, Chen S, et al. (2014). Induction of oxidative stress and the transcription of genes related to apoptosis in rare minnow (Gobiocypris rarus) larvae with Aroclor 1254 exposure. Ecotoxicol. Environ. Saf. 110: 254-260. http://dx.doi.org/10.1016/j.ecoenv.2014.09.012

Wu SM, Tsai JW, Tzeng WN, Chen WY, et al. (2015). Analyzing the effectiveness of using branchial NKA activity as a biomarker for assessing waterborne copper toxicity in tilapia (Oreochromis mossambicus): A damage-based modeling approach. Aquat. Toxicol. 163: 51-59. http://dx.doi.org/10.1016/j.aquatox.2015.03.016

Yadetie F, Karlsen OA, Eide M, Hogstrand C, et al. (2014). Liver transcriptome analysis of Atlantic cod (Gadus morhua) exposed to PCB 153 indicates effects on cell cycle regulation and lipid metabolism. BMC Genomics 15: 481. http:// dx.doi.org/10.1186/1471-2164-15-481

Zhao Y, Wang J, Thammaratsuntorn J, Wu JW, et al. (2015). Comparative transcriptome analysis of Nile tilapia (Oreochromis niloticus) in response to alkalinity stress. Genet. Mol. Res. 14: 17916-17926. http://dx.doi.org/10.4238/2015. December.22.16

Zheng Y, Liang H, Xu P, Li M, et al. (2014). Molecular cloning of Pcc-dmrtls and their specific expression patterns in Pengze crucian carp (Carassius auratus var. Pengze) affected by 17a-methyltestosterone. Fish Physiol. Biochem. 40: 1141-1155.

\section{Supplementary material}

Table S1. Tilapia primers used for qRT-PCR in the study of Oreochromis niloticus.

Genetics and Molecular Research 15 (3): gmr.15038620 